\title{
Towards Quantification of the Water Footprint of Paper: A First Estimate of its Consumptive Component
}

\author{
P. R. van Oel • A. Y. Hoekstra
}

Received: 5 July 2010 / Accepted: 31 October 2011 /

Published online: 16 November 2011

(C) The Author(s) 2011. This article is published with open access at Springerlink.com

\begin{abstract}
For a hardcopy of this article, printed in the Netherlands, an estimated 1001 of water have been used. Most of the water is required in the forestry stage, due to evapotranspiration (green and blue water). In addition, the water footprint during the industrial stage, as accounted for in this study, consists of evaporation from water obtained from ground water and surface water (blue water). In this study estimates are made of water requirements for producing paper using different types of wood and in different parts of the world. The water footprint of printing and writing paper is estimated to be between 300 and $2600 \mathrm{~m}^{3} / \mathrm{t}$ ( 2-13 1 for an A4 sheet). These estimates account for paper recovery rates in different countries. This study indicates that by using recovered paper for the production of paper the global average water footprint of paper is only $60 \%$ of what it would be if no recovered paper would be used at all. Further savings may be achieved by increasing the recovery percentages worldwide. In addition, the global water footprint of paper can be reduced by choosing production sites and wood types that are more water-efficient. The results of this study suggest that the use of recovered paper may be particularly effective in reducing water footprints. This study is a first step towards a better understanding of the significance of the water footprint of paper and the effect of using recovered paper.
\end{abstract}

Keywords Water footprint $\cdot$ Paper $\cdot$ Virtual water $\cdot$ Green water $\cdot$ Blue water $\cdot$ Recycling

\section{Introduction}

Forests are renewable resources that are key to the production of paper, since the main ingredient of paper is wood pulp (cellulose). Next to their importance for paper, forests are important for the production of other goods, such as timber and firewood, the conservation of biodiversity, the provision of socio-cultural services and carbon storage. Forests also play a vital role in catchment hydrology. Deforestation and afforestation affect hydrological processes in a way that may directly influence water availability. It is for instance well

P. R. van Oel $(\bowtie) \cdot$ A. Y. Hoekstra

University of Twente, Enschede, The Netherlands

e-mail: oel@itc.nl 
established that a reduction in runoff is expected with afforestation on grasslands and shrublands (e.g. Fahey and Jackson 1997; Wilk and Hughes 2002; Farley et al. 2005; Jackson et al. 2005).

Large amounts of freshwater are required throughout the supply chain of a product until the moment of consumption. For quantifying this amount, the water footprint concept can be used (Hoekstra and Chapagain 2007; 2008). The water footprint of a product is defined as the total amount of freshwater that is needed to produce it. The water footprint can contain green, blue and grey components. The green component is the volume of water evaporated from rainwater stored in or on the vegetation or stored in the soil as soil moisture. The blue component refers to evaporated surface and ground water. The grey component is the volume of polluted ground- and surface water. An increasing number of publications on virtual-water trade and water footprints of consumer products have been added to scientific literature recently. These include studies focussing on populations of countries or regions (e.g. Ge et al. 2011; Montesinos et al. 2011), specific consumer products (e.g. Ercin et al. 2011) and studies that discuss the way these concepts may be used (e.g. Aldaya et al. 2010; Wichelns 2010a; 2010b; Velázquez et al. 2011). So far, the water footprint of paper has not been studied in enough detail to reflect on its claims on water resources. This study is a first step towards a quantification of the water footprint of paper. In this study, a method for determining the water footprint of paper at the national level is proposed that takes into account both the forestry and the industrial stage of the production process. The scope is limited to a study of consumptive water use-considering both the green and blue water footprint. First, the water footprint of paper produced using pulp from the main pulp producing countries in the world is estimated, taking into account the use of recovered paper. To show the significance of the water footprint of paper, the results are applied to the case of the Netherlands.

\section{Method}

\subsection{Estimating the Water Footprint of Paper}

The water footprint during the forestry stage contains both a green and blue component. These two components cannot easily be determined separately as trees use rainfall water and tap from groundwater resources simultaneously. Therefore, in the scope of this study, we estimate the green and blue water footprint of paper as a total sum. During the industrial stage there is only a blue water footprint. The water footprint of a unit of paper $p$ (expressed in $\mathrm{m}^{3} / \mathrm{t}$ ) is estimated as follows:

$$
W F[p]=W F_{\text {forestry }}[p]+W F_{\text {industry }}[p]
$$

The water footprint of a unit of paper $p$ for the forestry stage is estimated as follows:

$$
W F_{\text {forestry }}[p]=\left(\frac{E T_{a}+\left(Y_{\text {wood }} \times f_{\text {water }}\right)}{Y_{\text {wood }}}\right) \cdot f_{\text {paper }} \times f_{\text {value }} \times\left(1-f_{\text {recycling }}\right)
$$

in which $E T_{a}$ is the actual evapotranspiration from a forest/woodland $\left(\mathrm{m}^{3} / \mathrm{ha} / \mathrm{year}\right), Y_{\text {wood }}$ the wood yield from a forest/woodland $\left(\mathrm{m}^{3} / \mathrm{ha} /\right.$ year $), f_{\text {water }}$ the volumetric fraction of water in freshly harvested wood $\left(\mathrm{m}^{3} / \mathrm{m}^{3}\right), f_{\text {paper }}$ the wood-to-paper conversion factor (i.e. the harvested volume needed to produce a metric ton of $\operatorname{paper}\left(\mathrm{m}^{3} / \mathrm{t}\right), f_{\text {value }}$ the fraction of total value of the forest which is associated with paper production (dimensionless) and $f_{\text {recycling }}$ 
the fraction of pulp derived from recycled paper (dimensionless). Note that the wood-topaper conversion factor relates to the so-called product fraction $\left(f_{p}\right.$, mass $/$ mass $)$ that is used in the standard calculation of a product water footprint (Hoekstra et al. 2009). The two parameters relate as follows:

$$
f_{\text {paper }}=\frac{1}{f_{p} \times \rho}
$$

with $\rho$ being the density of harvested wood $\left(\operatorname{ton} / \mathrm{m}^{3}\right)$.

The water footprint of a unit of paper $p$ for the industrial stage is estimated as follows:

$$
W F_{\text {industry }}[p]=E+R+P
$$

in which $E$ is the evaporation in the production process $\left(\mathrm{m}^{3} / \mathrm{t}\right), R$ the water contained in solid residuals $\left(\mathrm{m}^{3} / \mathrm{t}\right)$ and $P$ the water contained in products $\left(\mathrm{m}^{3} / \mathrm{t}\right)$.

\subsubsection{Step 1: Estimating Evapotranspiration (ET $T_{a}$ ) by Forest Type and by Country}

There are several factors that influence evapotranspiration from forest biomes, including meteorological conditions, tree type and forest management. To get an overview of evapotranspiration from forests at the global level, use is made of two data sources that are both obtained from FAO GeoNetwork (Fig. 1):

- The World's Forests 2000 (FAO 2001): this dataset is based on 1992-93 and 1995-96 AVHRR data and gives global distribution of forest biomes at a resolution of $1 \mathrm{~km}$. Five different forest types are distinguished: boreal (typical trees include pine, fir, and spruce), tropical (typical trees include eucalyptus), sub-tropical, temperate (typical trees include oak, beech and maple) and polar forest. Different forest types can be present in one country. For its low relevance, polar forests have been ignored.

- Annual actual evapotranspiration (FAO 2009b): this dataset contains annual average values for the period 1961-1990 at a resolution of 5 arc minutes.

With these data it is possible to obtain a rough estimate of annual evapotranspiration values for forests in most countries of the world. Country averages are determined by averaging all values of actual evapotranspiration in a country for all locations that are covered with closed forest. For calculating the water footprint of paper, evapotranspiration values for the 22 main global producers of pulp (FAO 2009a) are determined. Together, these countries produced $95 \%$ of globally produced pulp for the period 1998-2007. The locations from which wood is actually obtained remain unclear from statistics on pulp production. Therefore it is difficult to relate the right amount of evapotranspiration to the production of pulp. Due to a lack of detailed spatial information, in this study ranges of possible evapotranspiration values are presented, rather than estimates for actual forestry locations. Besides uncertainties on locations of origin within a producing country, also import from other countries may be important. Paper mills in Sweden, for example, use $75 \%$ of wood that originates from Sweden itself; the other 25\% is imported from Latvia, Estonia and Lithuania (GonzalezGarcia et al. 2009). These pre-processing international trade flows are not taken into account in this study.

Table 1 shows the average annual evapotranspiration for the main pulp producing countries by forest type. If only one forest type exists in a country, only one value will be 


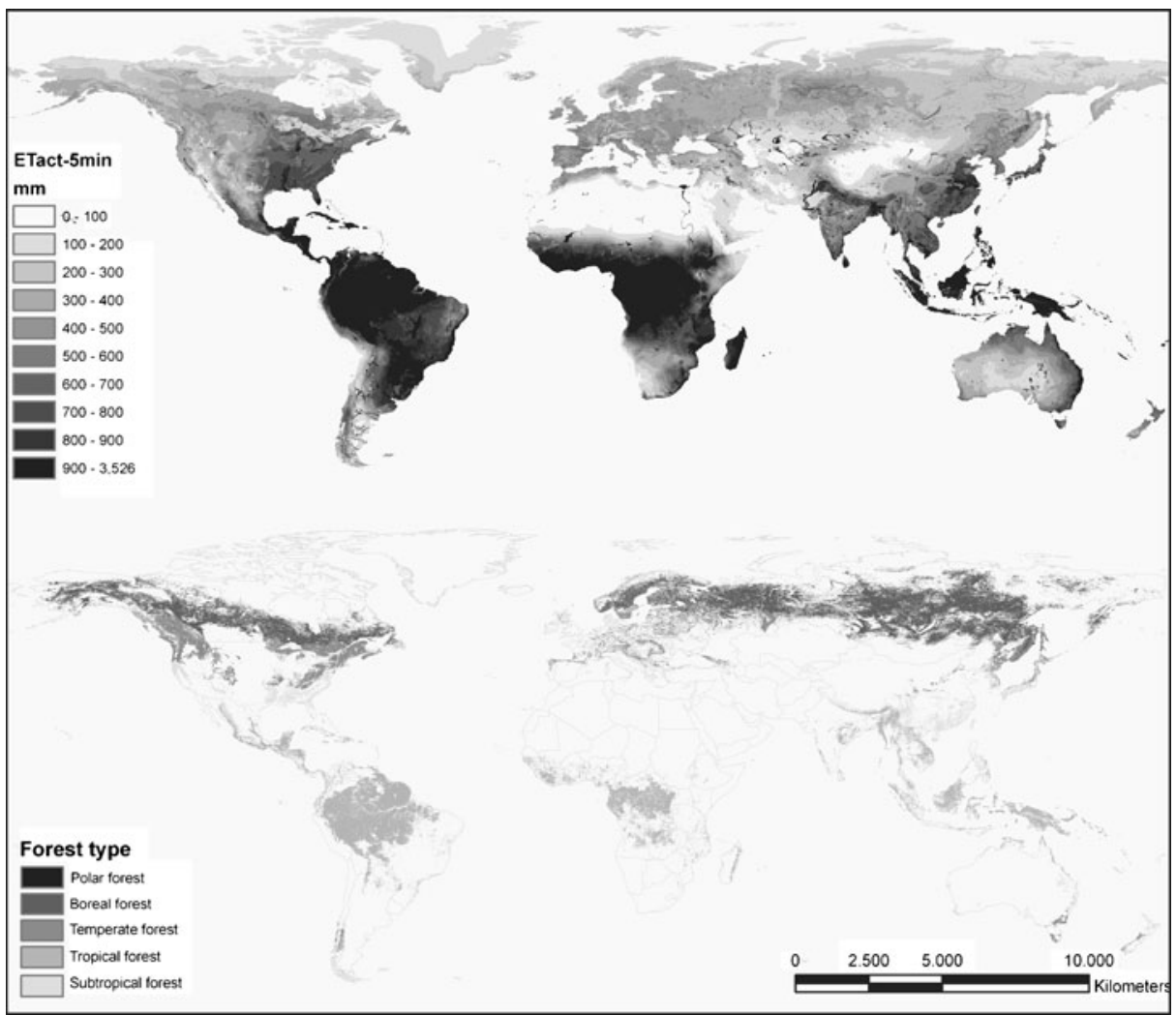

Fig. 1 Top: annual actual evapotranspiration (FAO 2009b). The dataset contains yearly values for global land areas for the period 1961-1990. Bottom: The World's Forests 2000 (FAO 2001) This database is based on 1992-93 and 1995-96 AVHRR data

considered. If more than one forest type exists, the values of all forest types are given. For large countries covering several climatic zones, such as the USA, values of evapotranspiration may vary considerably.

In this study, the green and blue water footprint requirements have been determined jointly. The difference between the use of green and the use of blue water is not as straightforward for forestry products as it is for other (agricultural) products. This difficulty is related to the process of water uptake by trees. The extent of the root zone of a full grown tree is generally well beyond the rainwater that is contained in the soil. Trees obtain water from the soil as well as from aquifers. In-depth studies on forest hydrology for specific cases would be required to come anywhere close to a reliable estimate of the ratio green/blue in the water footprint of forestry products.

\subsubsection{Step 2: Estimating Wood Yield ( $\left.Y_{\text {wood }}\right)$}

For this study it has been assumed that the wood used for the production of wood pulp is harvested at a rate corresponding to the maximum sustainable annual yield from productive forests with wood production as its primary function. We will reflect 
Table 1 Contribution to annual pulp production and estimates for average actual annual evapotranspiration by forest type in the main pulp-producing countries

\begin{tabular}{|c|c|c|c|c|c|c|}
\hline \multirow[t]{2}{*}{$\begin{array}{l}\text { Pulp producing } \\
\text { country }\end{array}$} & \multirow[t]{2}{*}{$\begin{array}{l}\text { Contribution to global } \\
\text { pulp production }^{\mathrm{a}}\end{array}$} & \multirow[t]{2}{*}{$\begin{array}{l}\text { Share of } \\
\text { chemical pulp }\end{array}$} & \multicolumn{4}{|c|}{$\begin{array}{l}\text { Average actual annual evapotranspiration by } \\
\text { forest type }(\mathrm{mm} / \mathrm{year})^{\mathrm{b}}\end{array}$} \\
\hline & & & Boreal & Temperate & Subtropical & Tropical \\
\hline USA & $29.5 \%$ & $85 \%$ & 278 & 516 & 635 & 1730 \\
\hline Canada & $13.5 \%$ & $52 \%$ & 358 & 360 & - & - \\
\hline China & $9.2 \%$ & $11 \%$ & 370 & 416 & 608 & 547 \\
\hline Finland & $6.5 \%$ & $60 \%$ & 355 & 293 & - & - \\
\hline Sweden & $6.3 \%$ & $69 \%$ & 345 & 318 & - & - \\
\hline Japan & $5.9 \%$ & $87 \%$ & - & 637 & 725 & - \\
\hline Brazil & $4.8 \%$ & $93 \%$ & - & - & 965 & 1048 \\
\hline Russia & $3.3 \%$ & $74 \%$ & 310 & 362 & - & - \\
\hline Indonesia & $2.4 \%$ & $93 \%$ & - & - & - & 1071 \\
\hline India & $1.7 \%$ & $37 \%$ & - & - & 455 & 551 \\
\hline Chile & $1.6 \%$ & $86 \%$ & - & 567 & 578 & - \\
\hline France & $1.3 \%$ & $67 \%$ & - & 401 & 386 & - \\
\hline Germany & $1.3 \%$ & $44 \%$ & - & 363 & - & - \\
\hline Norway & $1.2 \%$ & $26 \%$ & 328 & 303 & - & - \\
\hline Portugal & $1.0 \%$ & $100 \%$ & - & 512 & 502 & - \\
\hline Spain & $1.0 \%$ & $93 \%$ & - & 547 & 527 & - \\
\hline South Africa & $1.0 \%$ & $72 \%$ & - & - & 819 & 762 \\
\hline Austria & $0.9 \%$ & $76 \%$ & - & 344 & - & - \\
\hline New Zealand & $0.8 \%$ & $45 \%$ & - & 491 & 630 & - \\
\hline Australia & $0.6 \%$ & $50 \%$ & - & 768 & 775 & 818 \\
\hline Poland & $0.6 \%$ & $76 \%$ & - & 377 & - & - \\
\hline Thailand & $0.5 \%$ & $86 \%$ & - & - & - & 636 \\
\hline Total & $94.8 \%$ & & & & & \\
\hline
\end{tabular}

${ }^{a}$ Data source: annual averages for the period 1996-2005 based on FAOSTAT data (FAO 2009a)

${ }^{b}$ Data sources: national averages estimates based on grid data from FAO $(2001 ; 2009 b)$

upon this approach in the discussion section. Data on wood products are obtained from the Global Forest Resources Assessment 2005 (FAO 2006). The estimates used in this study are presented in Table 2. Tree types are categorized into pine, eucalyptus and broadleaves. In this study the following assumptions are made for tree types in different forest biomes:

- Boreal forests yield pine

- Temperate forests yield broadleaves and pine

- Subtropical and tropical forests yield eucalyptus

\subsubsection{Step 3: Fraction of Water in Harvested Wood $\left(f_{\text {water }}\right)$}

Generally this fraction is around $0.4 \mathrm{~m}^{3}$ of water per $\mathrm{m}^{3}$ of freshly harvested wood (e.g. Gonzalez-Garcia et al. 2009; NCASI 2009). A large part of the water may be returned to surface or ground water during the industrial manufacturing process. It is however removed 
Table 2 Wood yield estimates for the main pulp-producing countries

${ }^{a}$ Data source: FAO (2006)

${ }^{\mathrm{b}}$ Continental averages from available data are assumed

${ }^{\mathrm{c}}$ European continental averages are used. In the case of Canada and the United States this is due to a lack of available data. For Russia, a European average is assumed to be more representative than the Asian continental average

\begin{tabular}{llll}
\hline \multirow{2}{*}{ Pulp producing country } & \multicolumn{3}{l}{ Wood yield estimates $\left(\mathrm{m}^{3} / \text { ha/year }\right)^{\mathrm{a}}$} \\
\cline { 2 - 4 } & Broadleaves & Eucalyptus & Pine \\
\hline USA & $7^{\mathrm{c}}$ & $16^{\mathrm{c}}$ & 6 \\
Canada & $7^{\mathrm{c}}$ & & $6^{\mathrm{b}}$ \\
China & 6 & 6 & 4 \\
Finland & 7 & & 6 \\
Sweden & $7^{\mathrm{b}}$ & & $8^{\mathrm{b}}$ \\
Japan & 11 & 14 & $7^{\mathrm{b}}$ \\
Brazil & 20 & 45 & \\
Russia & $7^{\mathrm{c}}$ & & $8^{\mathrm{c}}$ \\
Indonesia & & 19 & \\
India & & 10 & \\
Chile & 22 & 26 & 19 \\
France & $7^{\mathrm{b}}$ & $16^{\mathrm{b}}$ & 9 \\
Germany & $7^{\mathrm{b}}$ & & $8^{\mathrm{b}}$ \\
Norway & $7^{\mathrm{b}}$ & & $8^{\mathrm{b}}$ \\
Portugal & $7^{\mathrm{b}}$ & $16^{\mathrm{b}}$ & $8^{\mathrm{b}}$ \\
Spain & $7^{\mathrm{b}}$ & $16^{\mathrm{b}}$ & $8^{\mathrm{b}}$ \\
South Africa & 11 & 23 & $8^{\mathrm{b}}$ \\
Austria & $7^{\mathrm{b}}$ & & 15 \\
New Zealand & 14 & $19^{\mathrm{b}}$ & 12 \\
Australia & $14^{\mathrm{b}}$ & 19 & 7 \\
Poland & 8 & & \\
Thailand & & $14^{\mathrm{b}}$ & \\
\hline & & & \\
\hline
\end{tabular}

from the forest area and should therefore be accounted for in the water footprint in the forestry stage.

\subsubsection{Step 4: Wood-to-Paper Conversion Factors ( $\left.f_{\text {paper }}\right)$}

This is the amount of wood needed to produce a certain mass of paper $\left(\mathrm{m}^{3} / \mathrm{t}\right)$. Estimates for important products are obtained from the UNECE conversion factors report (UNECE/FAO 2010). The main conversion factors are summarized in Table 3. The product categories used in this study are based on the categories as used in the ForestSTAT database (FAO 2009a). For different kinds (and qualities) of paper different types of pulp are used. The pulp differs according to the type of pulping technique that is applied. In this study no differences are made for different tree types.

\subsubsection{Step 5: Estimating the Fraction of Total Value of the Forest Associated with Paper Production $\left(f_{\text {value }}\right)$}

Forests generally serve multiple functions, one of which may be the production of paper. Others may be the production of timber, biodiversity conservation and carbon storage. Therefore, not all evapotranspiration from a forest should necessarily be attributed to the production of paper. A value fraction (Hoekstra and Chapagain 2008) could be determined 
Table 3 Wood-to-paper conversion factors

\begin{tabular}{|c|c|c|c|}
\hline Product & $\begin{array}{l}\text { FAO product code } \\
(\text { FAO 2009a) }\end{array}$ & $\begin{array}{l}\text { ITC product group } \\
\text { codes used (ITC 2006) }\end{array}$ & $\begin{array}{l}\text { Conversion factors } \\
\text { based on UNECE/ } \\
\text { FAO }(2010)\left(\mathrm{m}^{3} / \mathrm{t}\right)\end{array}$ \\
\hline Mechanical Wood Pulp & 1654 & 2512 & 2.50 \\
\hline Semi-Chemical Wood Pulp & 1655 & 25191 & 2.67 \\
\hline Chemical Wood Pulp & 1656 & $2514,2515,2516$ & 4.49 \\
\hline Dissolving Wood Pulp & 1667 & 2513 & 5.65 \\
\hline Recovered Paper & 1669 & 2511 & \\
\hline Newsprint & 1671 & 6411 & 2.87 \\
\hline Printing \& Writing Paper & 1674 & 6412,6413 & 3.51 \\
\hline Other Paper \& Paperboard & 1675 & $6414,6415,6416,6417,6419,642$ & 3.29 \\
\hline
\end{tabular}

to allocate the amount of water to be allocated to the production of wood pulp for a forest with $n$ functions, including the production of wood pulp:

$$
f_{\text {value }}[\text { pulp }]=\frac{\text { value }[\text { pulp }]}{\sum_{i=1}^{n} \text { value }[i]}
$$

In this study it is assumed that paper is produced from forests that have wood/pulp production as the primary function and for which annual growth is equal to annual harvest, so we assume the value fraction to be equal to 1 . We will come back to this issue in the discussion section.

\subsubsection{Step 6: Estimating the Fraction of Pulp Derived From Recovered Paper (frecycling}

Recycling is an important factor for the water footprint, because fully recycled paper avoids the use of fresh wood and thus nullifies the water footprint in the forestry stage. When more recovered paper is used, the overall water footprint will decrease. On average an estimated $41 \%$ of all produced pulp is obtained from recycled paper (FAO/CEPI 2007; UNECE/FAO 2010), with large differences between producers using no recycled paper at all to producers that achieve relatively high percentages. We obtained the 'recovered paper utilization rates' for the main pulp producing countries from (FAO/CEPI 2007). The 'recovered paper utilization rate' is the amount of recovered paper used for paper and paperboard as a percentage of paper and paperboard production. Losses in repulping of recovered paper are estimated to be between 10 and $20 \%$ (FAO/CEPI 2007). In this study, $15 \%$ is used for all countries. The values used in this study are summarized in Table 4 . The product categories for which recycling is taken into account are only the consumer product categories (i.e. newsprint, 'printing \& writing paper' and 'other paper \& paperboard'), since these are the only categories for which it is actually used.

\subsubsection{Step 7: Estimating the Water Footprint of Paper in the Forestry Stage}

For a quantification of the water footprint of paper in the forestry stage, estimates for the main pulp producing countries are made, as listed in Table 1. 
Table 4 Recovered paper utilization rates and $f_{\text {recycling }}$ for the main pulp-producing countries
${ }^{a}$ Data source: (FAO/CEPI 2007)

b $85 \%$ of recovered paper utilization rate assumed due to loss in processing

${ }^{\mathrm{c}}$ When no data are available for the individual country, the average of the other countries is used

\begin{tabular}{lll}
\hline Country & $\begin{array}{l}\text { Recovered } \\
\text { paper utilization rate }\end{array}$ & $\begin{array}{l}\text { Fraction of pulp derived } \\
\text { from recycled paper } \\
\left(f_{\text {recycling }}\right)^{\mathrm{b}}\end{array}$ \\
\hline USA & 0.37 & 0.31 \\
Canada & 0.24 & 0.20 \\
China & $0.42^{\mathrm{a}}$ & 0.36 \\
Finland & 0.05 & 0.04 \\
Sweden & 0.17 & 0.14 \\
Japan & 0.61 & 0.52 \\
Brazil & 0.40 & 0.34 \\
Russia & $0.42^{\mathrm{c}}$ & 0.36 \\
Indonesia & $0.42^{\mathrm{c}}$ & 0.36 \\
India & $0.42^{\mathrm{c}}$ & 0.36 \\
Chile & 0.42 & 0.36 \\
France & 0.60 & 0.51 \\
Germany & 0.67 & 0.57 \\
Norway & 0.22 & 0.19 \\
Portugal & 0.21 & 0.18 \\
Spain & 0.85 & 0.72 \\
South Africa & $0.42^{\mathrm{c}}$ & 0.36 \\
Austria & 0.46 & 0.39 \\
New Zealand & 0.25 & 0.21 \\
Australia & 0.64 & 0.54 \\
Poland & 0.36 & 0.31 \\
Thailand & 0.59 & 0.50 \\
Average of main pulp & 0.42 & 0.36 \\
producing countries & & 0.60 \\
Netherlands & 0.70 & \\
\hline & & \\
\hline
\end{tabular}

\subsubsection{Step 8: Estimating the Water Footprint of Paper in the Industrial Stage}

The water footprint of paper in the industrial stage of production is estimated based on the case of the USA, considering the country's paper and pulp production sector as a whole (NCASI 2009). The USA is the largest producer of paper pulp and is assumed to be representative for the global paper industry. In this study no comparison is made between different techniques and processes that may be used in producing pulp.

In this study a number of processes with potentially significant contributions to the water footprint of paper have been ignored. These processes include: finalizing paper product and getting it to the consumer. In this process machines, several materials and energy sources are used. Also transportation has not been accounted for. For transportation a variety of alternative sources of energy may be used, including fossil fuels and bioenergy. Particularly when bioenergy is involved, the water footprint in transportation may be substantial (Gerbens-Leenes et al. 2009).

\subsection{Estimating the Water Footprint of Paper Consumption in a Country}

Many countries strongly depend on imports of pulp and paper. For those countries it is relevant to know the water footprints of the imported products and where these water 
footprints are located. This will be shown in a case study for the Netherlands. As a basis, we use data on the annual production, import, export and consumption of paper for the Netherlands as shown in Table 5.

A weighted average for all import partners is made for a few different paper products, similar to the way it is done by van Oel et al. (2009) and Hoekstra et al. (2009). Data on imports specified by trade partner are used from the International Trade Centre (ITC 2006). Table 3 shows the product categories used for estimating the water footprints of imported paper products. The average water footprint $W F^{*}$ of a paper product $p$ consumed in the Netherlands $(N L)$ is estimated by assuming that:

$$
W F^{*}[N L, p]=\frac{P[N L] \times W F[N L, p]+\sum_{c=1}^{m}(I[c] \times W F[c, p])}{P[N L]+\sum_{c=1}^{m} I[c]}
$$

in which $W F[N L, p]$ is the water footprint of paper product $p$ produced in the Netherlands using Dutch pulp; $W F[c, p]$ the water footprint of paper product $p$ produced in the Netherlands using pulp from country $c ; P[N L]$ the production of wood equivalents in the Netherlands, and $I[c]$ the import of wood equivalents into the Netherlands from country $c$. The various sorts of pulp produced in and imported into the Netherlands are expressed in wood equivalents using the conversion factors as shown in Table 3. The assumption here is that paper products are based on domestic and imported pulp according to the ratio of domestic pulp production to pulp import. On the Dutch market, in the period 1996-2005, 6\% of the available pulp (expressed in terms of wood equivalents) had domestic origin; the remaining $94 \%$ was imported.

\section{Results}

\subsection{The Water Footprint of Paper}

The evapotranspiration per volume of harvested wood for the main pulp producing countries is shown in Table 6. The water footprint of paper is shown in Tables 7, 8 and 9. Country-specific recycling percentages are incorporated in these values. The lowest estimate for printing \& writing paper is $321 \mathrm{~m}^{3} / \mathrm{t}$ (eucalyptus from subtropical biome in Spain) and the highest value is $2602 \mathrm{~m}^{3} / \mathrm{t}$ (eucalyptus from tropical biome in the USA), corresponding to 2 and 131 per sheet of standard A4 copy paper respectively. If no recovered paper would have been used, these values would become $753 \mathrm{~m}^{3} / \mathrm{t}$ (eucalyptus

Table 5 Annual production, import, export and consumption for the Netherlands for the period 1996-2005

\begin{tabular}{lllll}
\hline Product & Pulp & Newsprint & $\begin{array}{l}\text { Printing \& writing } \\
\text { paper }\end{array}$ & Other paper \& paperboard \\
\hline FAO code & $1654-56,1667$ & 1671 & 1674 & 1675 \\
Production (ton/year) $^{\mathrm{a}}$ & 125350 & 387700 & 895400 & 1987200 \\
Import quantity (ton/year) $^{\mathrm{a}}$ & 1132860 & 476540 & 1267890 & 1498200 \\
Export quantity (ton/year) $^{\mathrm{a}}$ & 322340 & 259480 & 1143450 & 1417900 \\
Consumed (ton/year) & 935870 & 604760 & 1019840 & 2067500 \\
\hline
\end{tabular}

\footnotetext{
${ }^{\text {a }}$ Source: ForestStat (FAO 2009a)
} 
Table 6 Water footprint of harvested wood for the main pulp-producing countries

\begin{tabular}{|c|c|c|c|c|c|}
\hline \multirow{2}{*}{$\begin{array}{l}\text { Pulp producing } \\
\text { country }\end{array}$} & \multicolumn{5}{|c|}{ Water footprint for different trees and places of origin $\left(\mathrm{m}^{3} / \mathrm{m}^{3}\right)$} \\
\hline & $\begin{array}{l}\text { Pines from } \\
\text { Boreal biome }\end{array}$ & $\begin{array}{l}\text { Pines from } \\
\text { Temperate biome }\end{array}$ & $\begin{array}{l}\text { Broadleaves from } \\
\text { Temperate biome }\end{array}$ & $\begin{array}{l}\text { Eucalyptus from } \\
\text { Subtropical biome }\end{array}$ & $\begin{array}{l}\text { Eucalyptus from } \\
\text { Tropical biome }\end{array}$ \\
\hline USA & 463 & 860 & 752 & 397 & 1081 \\
\hline Canada & 597 & 600 & 525 & & \\
\hline China & 891 & 1001 & 693 & 1105 & 995 \\
\hline Finland & 592 & 488 & 451 & & \\
\hline Sweden & 413 & 381 & 463 & & \\
\hline Japan & & 859 & 571 & 527 & \\
\hline Brazil & & & & 214 & 233 \\
\hline Russia & 371 & 434 & 528 & & \\
\hline Indonesia & & & & & 564 \\
\hline India & & & & 455 & 551 \\
\hline Chile & & 298 & 262 & 222 & \\
\hline France & & 446 & 584 & 241 & \\
\hline Germany & & 435 & 529 & & \\
\hline Norway & 393 & 363 & 442 & & \\
\hline Portugal & & 613 & 746 & 314 & \\
\hline Spain & & 655 & 797 & 329 & \\
\hline South Africa & & & & 356 & 331 \\
\hline Austria & & 412 & 501 & & \\
\hline New Zealand & & 335 & 351 & 338 & \\
\hline Australia & & 662 & 549 & 415 & 438 \\
\hline Poland & & 539 & 459 & & \\
\hline Thailand & & & & & 463 \\
\hline
\end{tabular}

from subtropical biome in Brazil) for the lower estimate and the higher estimate would be $3880 \mathrm{~m}^{3} / \mathrm{t}$ (eucalyptus from subtropical biome in China). For one sheet of A4 copy paper this means 4 and 191 respectively.

\subsubsection{Water Footprint of Paper in Industrial Stage-Example USA}

In the USA, annual industrial production of paper is around $97 \times 10^{6} \mathrm{t} /$ year. The total water use for the main water consumption categories is: $E=507 \times 10^{6} \mathrm{~m}^{3}, \mathrm{R}=19 \times 10^{6} \mathrm{~m}^{3}$, $\mathrm{P}=10 \times 10^{6} \mathrm{~m}^{3}$ (Fig. 2). A rough estimate then gives an average value of $5.5 \mathrm{~m}^{3} / \mathrm{t}$.

\subsection{The Water Footprint of Paper Consumption in the Netherlands}

The Dutch water footprint related to the consumption of paper is significant if compared to the footprint related to the consumption of other products. The water footprint of paper is estimated to constitute $8-11 \%$ of the total water footprint of Dutch consumption (Van Oel et al. 2009). Figure 3 gives a summary of the water footprint accounts for the Netherlands insofar related to paper consumption, production and trade. Minimum and maximum estimates are given to account for the fact that paper can have a low or high water footprint depending on the biome from which the wood is derived (Tables 7,8 and 9). 
Table 7 Water footprint of newsprint $\left(\mathrm{m}^{3} / \mathrm{t}\right)$, taking into account country-specific recovered paper utilization rates

\begin{tabular}{|c|c|c|c|c|c|}
\hline Country & $\begin{array}{l}\text { Pine from } \\
\text { boreal biome }\end{array}$ & $\begin{array}{l}\text { Pine from } \\
\text { temperate biome }\end{array}$ & $\begin{array}{l}\text { Broadleaf from } \\
\text { temperate biome }\end{array}$ & $\begin{array}{l}\text { Eucalyptus from } \\
\text { subtropical biome }\end{array}$ & $\begin{array}{l}\text { Eucalyptus from } \\
\text { tropical biome }\end{array}$ \\
\hline USA & 912 & 1692 & 1479 & 781 & 2127 \\
\hline Canada & 1363 & 1371 & 1199 & & \\
\hline China & 1648 & 1852 & 1282 & 2045 & 1840 \\
\hline Finland & 1626 & 1342 & 1239 & & \\
\hline Sweden & 1015 & 935 & 1138 & & \\
\hline Japan & & 1187 & 789 & 729 & \\
\hline Brazil & & & & 406 & 441 \\
\hline Russia & 687 & 802 & 976 & & \\
\hline Indonesia & & & & & 1043 \\
\hline India & & & & 842 & 1019 \\
\hline Chile & & 551 & 483 & 410 & \\
\hline France & & 627 & 822 & 339 & \\
\hline Germany & & 537 & 654 & & \\
\hline Norway & 917 & 847 & 1030 & & \\
\hline Portugal & & 1446 & 1759 & 740 & \\
\hline Spain & & 522 & 635 & 262 & \\
\hline South Africa & & & & 659 & 613 \\
\hline Austria & & 720 & 876 & & \\
\hline New Zealand & & 757 & 793 & 763 & \\
\hline Australia & & 866 & 718 & 543 & 573 \\
\hline Poland & & 1073 & 914 & & \\
\hline Thailand & & & & & 662 \\
\hline
\end{tabular}

Table 10 shows the water footprint of paper in the Netherlands, whereby a distinction is made between: (i) paper produced from trees grown in the Netherlands, (ii) imported paper to the Netherlands or paper produced from imported pulp, and (iii) the weighted average. The water footprint of paper produced from trees grown in the Netherlands is substantially lower (two to three times) than that of imported paper or paper produced from imported pulp. Most of the imported pulp originates from other European countries (85\%), followed by North America (12\%) (Fig. 4).

If countries from which the Netherlands imports pulp and paper would not recover paper as they currently do (Table 4) and if also the Netherlands itself would not recover paper, the water footprint of paper products consumed in the Netherlands would be $4.9-7.1 \mathrm{Gm}^{3} / \mathrm{yr}$. Using recovered paper has thus resulted in a water saving of $\sim 36 \%$. For the Netherlands, the water footprint of a standard A4 copy paper $\left(80 \mathrm{~g} / \mathrm{m}^{2}\right)$ is between 5 and 71 ( $7-101$ if no recovered paper is used).

\section{Discussion and Conclusion}

This numbers presented in this paper are only a first step towards a reliable estimate of the water footprint of paper. Nonetheless, this study shows that the water footprint of paper is highly significant and deserves to be studied in more detail. 
Table 8 Water footprint of 'printing \& writing paper' $\left(\mathrm{m}^{3} / \mathrm{t}\right)$, taking into account country-specific recovered paper utilization rates

\begin{tabular}{|c|c|c|c|c|c|}
\hline Country & $\begin{array}{l}\text { Pine from } \\
\text { boreal biome }\end{array}$ & $\begin{array}{l}\text { Pine from } \\
\text { temperate biome }\end{array}$ & $\begin{array}{l}\text { Broadleaf from } \\
\text { temperate biome }\end{array}$ & $\begin{array}{l}\text { Eucalyptus from } \\
\text { subtropical biome }\end{array}$ & $\begin{array}{l}\text { Eucalyptus from } \\
\text { tropical biome }\end{array}$ \\
\hline USA & 1115 & 2069 & 1809 & 955 & 2602 \\
\hline Canada & 1667 & 1676 & 1466 & & \\
\hline China & 2015 & 2266 & 1568 & 2501 & 2250 \\
\hline Finland & 1988 & 1641 & 1515 & & \\
\hline Sweden & 1241 & 1144 & 1392 & & \\
\hline Japan & & 1452 & 965 & 891 & \\
\hline Brazil & & & & 497 & 540 \\
\hline Russia & 840 & 981 & 1193 & & \\
\hline Indonesia & & & & & 1275 \\
\hline India & & & & 1029 & 1246 \\
\hline Chile & & 674 & 591 & 502 & \\
\hline France & & 766 & 1005 & 415 & \\
\hline Germany & & 657 & 799 & & \\
\hline Norway & 1121 & 1036 & 1260 & & \\
\hline Portugal & & 1769 & 2151 & 905 & \\
\hline Spain & & 638 & 776 & 321 & \\
\hline South Africa & & & & 806 & 749 \\
\hline Austria & & 881 & 1072 & & \\
\hline New Zealand & & 925 & 969 & 933 & \\
\hline Australia & & 1060 & 878 & 665 & 701 \\
\hline Poland & & 1312 & 1118 & & \\
\hline Thailand & & & & & 809 \\
\hline
\end{tabular}

The water footprint of printing and writing paper is estimated to be between 300 and $2600 \mathrm{~m}^{3} / \mathrm{t}$ (2-13 1 for an A4 sheet). In these estimates paper recovery rates in different countries (Table 5) are accounted for.

This study indicates that by using recovered paper for the production of paper the global average water footprint of paper is only $60 \%$ of what it would be if no recovered paper would be used at all. Further savings may be achieved by increasing the recovery percentages worldwide. The global water footprint of paper can be reduced by choosing production sites and wood types that are more water-efficient. The results of this study suggest that the use of recovered paper may be particularly effective in reducing the water footprint of paper. In addition, the global water footprint of paper can be reduced by choosing production sites and wood types that are more water-efficient.

For countries with a low recovered paper utilization rate a lot of room for reduction of the water footprint remains. In some countries such as the Netherlands, Spain and Germany a lot of recovered paper is already used. For the Netherlands, the water footprint related to the consumption of paper is significant. The water footprint of paper products is estimated to constitute $8-11 \%$ of the total water footprint of Dutch consumption.

In this study only a first rough estimate for the water footprint of paper has been made. To arrive at this estimate several assumptions and simplifications have been made. Below, some important assumptions are described and commented upon briefly. 
Table 9 Water footprint of 'other paper \& paperboard' $\left(\mathrm{m}^{3} / \mathrm{t}\right)$, taking into account country-specific recovered paper utilization rates

\begin{tabular}{|c|c|c|c|c|c|}
\hline Country & $\begin{array}{l}\text { Pine from } \\
\text { boreal biome }\end{array}$ & $\begin{array}{l}\text { Pine from } \\
\text { temperate biome }\end{array}$ & $\begin{array}{l}\text { Broadleaf from } \\
\text { temperate biome }\end{array}$ & $\begin{array}{l}\text { Eucalyptus from } \\
\text { subtropical biome }\end{array}$ & $\begin{array}{l}\text { Eucalyptus from } \\
\text { tropical biome }\end{array}$ \\
\hline USA & 1045 & 1940 & 1696 & 895 & 2439 \\
\hline Canada & 1563 & 1571 & 1374 & & \\
\hline China & 1889 & 2124 & 1470 & 2344 & 2109 \\
\hline Finland & 1864 & 1538 & 1420 & & \\
\hline Sweden & 1163 & 1072 & 1304 & & \\
\hline Japan & & 1361 & 904 & 835 & \\
\hline Brazil & & & & 466 & 506 \\
\hline Russia & 787 & 920 & 1119 & & \\
\hline Indonesia & & & & & 1195 \\
\hline India & & & & 965 & 1168 \\
\hline Chile & & 631 & 554 & 470 & \\
\hline France & & 718 & 942 & 389 & \\
\hline Germany & & 616 & 749 & & \\
\hline Norway & 1051 & 971 & 1181 & & \\
\hline Portugal & & 1658 & 2017 & 848 & \\
\hline Spain & & 598 & 728 & 301 & \\
\hline South Africa & & & & 755 & 702 \\
\hline Austria & & 826 & 1004 & & \\
\hline New Zealand & & 867 & 909 & 874 & \\
\hline Australia & & 993 & 823 & 623 & 657 \\
\hline Poland & & 1230 & 1048 & & \\
\hline Thailand & & & & & 759 \\
\hline
\end{tabular}

No detailed study was devoted to the differences between production systems for wood and wood pulp. Therefore, the uncertainty about the water footprint of paper is considerable and not accounted for in this study. Also, rather than accounting for evapotranspiration for the whole period between planting and harvesting, the average annual evapotranspiration from an extended area of forest has been used for the estimates presented. This implies

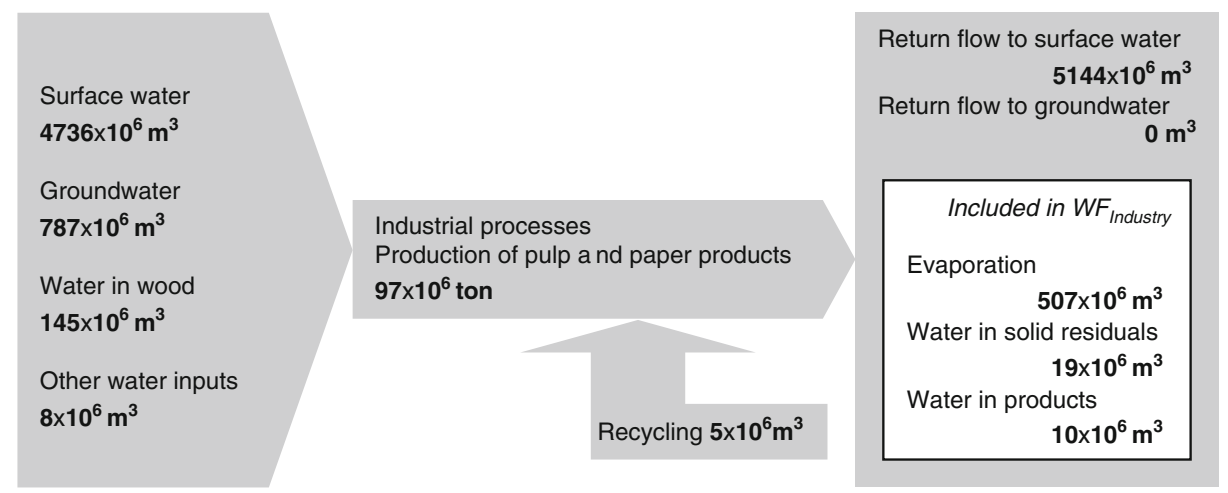

Fig. 2 Water flows in the paper and pulp industry in the USA (NCASI 2009) 

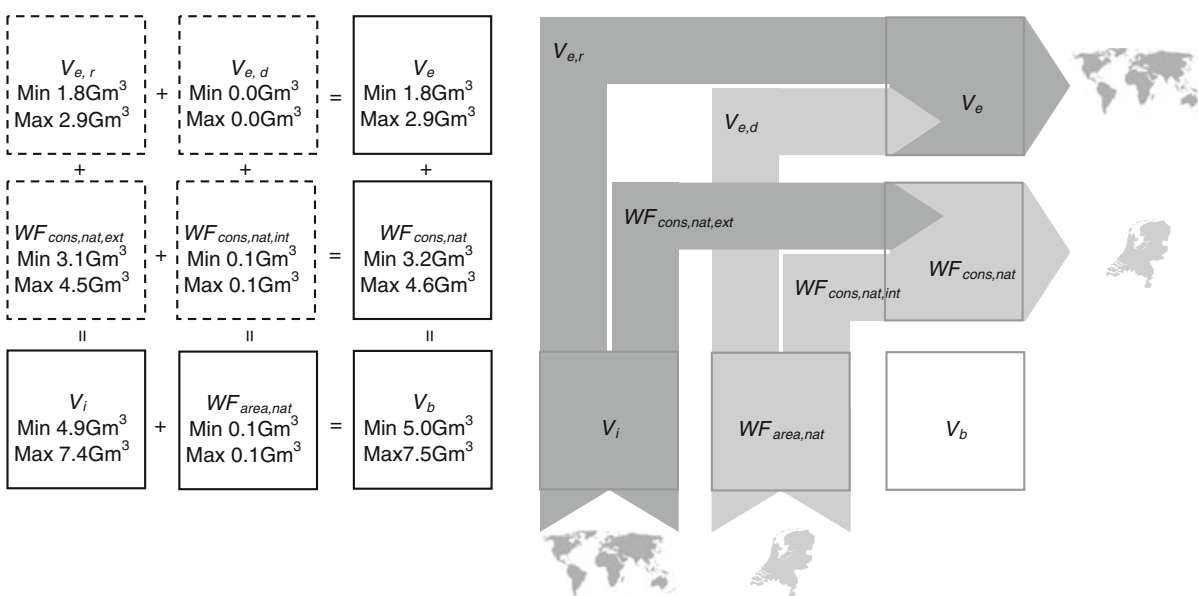

Fig. 3 Summary of the water footprint accounts for the Netherlands insofar related to paper consumption, production and trade: virtual-water import $\left(\mathrm{V}_{\mathrm{i}}\right)$, virtual-water export $\left(\mathrm{V}_{\mathrm{e}}\right)$, the water footprint within the area of the nation ( $\left.\mathrm{WF}_{\text {area,nat }}\right)$ the water footprint related to national consumption $\left(\mathrm{WF}_{\text {cons,nat }}\right)$, the external water footprint $\left(\mathrm{WF}_{\text {cons,nat,ext }}\right)$, the internal water footprint $\left(\mathrm{WF}_{\text {cons,nat.int }}\right)$, the virtual-water re-export $\left(\mathrm{V}_{\mathrm{e}, \mathrm{r}}\right)$ and the virtual-water export from domestic production $\left(\mathrm{V}_{\mathrm{e}, \mathrm{d}}\right)$. The numbers in the boxes are minimum and maximum estimates for the period 1996-2005

gradual harvesting over a long period of time. This may very well be far from what is happening in reality. Moreover, in estimating the water footprints of paper, annual meteorological variations or changes over longer periods of time have not been accounted for. For evapotranspiration, climate averages have been used (for the period 1961-1990).

For the data on wood yield used in this study (FAO 2006), the maximum sustainable annual yield has been assumed. This may again deviate considerably from actual maximum sustainable annual yields for the woodlands and forests concerned. The maximum sustainable annual yield is the maximum annual yield that can be obtained from a forested

Table 10 Water footprint of paper products in the Netherlands

\begin{tabular}{llll}
\hline Origin & & Water footprint $\left(\mathrm{m}^{3} / \mathrm{t}\right)$ \\
\cline { 3 - 3 } & & Lower estimate & Higher estimate \\
\hline Paper produced from trees grown in the & Newsprint & 369 & 410 \\
Netherlands & Printing \& writing paper & 451 & 501 \\
& Other paper \& paper board & 423 & 470 \\
Imported paper to the Netherlands or paper & Newsprint & 829 & 1144 \\
produced from imported pulp & Printing \& writing paper & 994 & 1402 \\
& Other paper \& paper board 848 & 1267 \\
Average paper as on the Dutch market ${ }^{\mathrm{a}}$ & Newsprint & 802 & 1101 \\
& Printing \& writing paper & 962 & 1349 \\
& Other paper \& paper board & 823 & 1221 \\
\hline
\end{tabular}

${ }^{\text {a }}$ For the production of these products in the Netherlands it is assumed that pulp is used from imported and domestic sources in the same ratio as they are available (imported+produced). Around $94 \%$ of the available pulp in the Netherlands is imported 


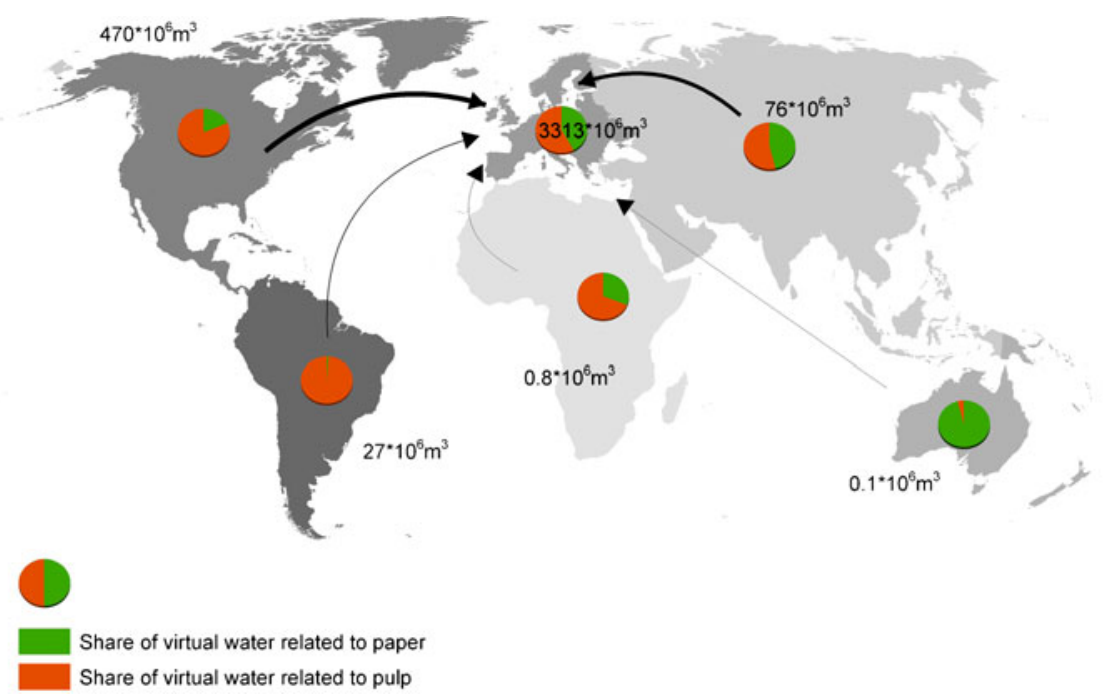

Fig. 4 Virtual-water imports to the Netherlands by continent related to the import of pulp and paper

area over an extended period of time. If the reported yield is less than this figure the water footprint estimate that is calculated for that forest in this study is an overestimation, since in that case not all of the forest (and the evapotranspiration of that forest) is actually used for production of wood for the paper industry. Per biome we have estimated the maximum sustainable annual yield by assuming one typical tree type. In reality, many forest biomes are mixed with regard to tree types. For a boreal forest biome, pine trees have been assumed when taking data for the maximum sustainable annual yield, which is not precisely the case for all areas that are classified as boreal biome. For temperate, subtropical and tropical biomes, tree diversity may be even higher. Since actual evapotranspiration estimates are used for biomes rather than for specific tree types, this may off course cause significant inaccuracies. By studying specific cases in more detail uncertainties may be reduced considerably.

Moreover, in this study the functions of a woodland or forest, other than the production of wood for the paper industry are not accounted for at all. Many planted forests are monocultures of introduced species, unlike the assumption of representative biomes as assumed in this study. Moreover, these introduced species are often not even found in the natural biome. When analyzing cases with specific species, more precise data should be studied to reduce uncertainty. Moreover, woodlands like semi-natural forests and plantations often serve purposes of considerable importance next to that of delivering wood for the production of paper. Next to the production of timber, important functions include biodiversity conservation and carbon storage. A possible way of accounting would be to allocate the forest-ET over the various forest functions according to their economic value (Hoekstra 2009). One would need estimates of the various values of forests, as for instance reported in Costanza et al. (1997).

When recovered paper is used for producing new paper one could decide to account for the water footprint in the forestry stage of the original wood that was used for producing the recovered paper. In this study that part of the water footprint is not accounted for. Thus, in this study the pulp from recycled paper has no forestry-related water footprint. If one would decide to do take into account this part of the water footprint then one still has to decide on 
the water footprint of the recovered paper that was used to produce the newly recovered paper and so on. Moreover, in theory one could decide to reduce the water footprint op paper if one assumes that this paper in the future will be recycled. However, beforehand it is not known how many times (if at all) a paper product will be recycled. If one would be able to precisely trace recycling flows, one could also allocate the water footprint in the first stage of wood production to the final paper products produced in the different recycling stages, so that (decreasing) fractions of the forestry-related water footprint are allocated to the paper products in the subsequent recycling stages. If one is interested in estimating the water footprint of a specific paper product produced in a particular paper mill using a specific mixture of wood pulp and recycled paper-pulp, one would need to study the process in much more detail than has been done in this study. The current study is a macro study, where the total annual water footprint in the forestry stage of paper production is allocated to the total annual paper production, whereby the latter is partly based on recycled paper. This study could serve as a first step towards understanding the significance of the water footprint of paper and exploring ways to reduce its negative impacts.

Open Access This article is distributed under the terms of the Creative Commons Attribution Noncommercial License which permits any noncommercial use, distribution, and reproduction in any medium, provided the original author(s) and source are credited.

\section{References}

Aldaya MM, Martínez-Santos P, Llamas MR (2010) Incorporating the water footprint and virtual water into policy: Reflections from the Mancha Occidental region, Spain. Water Resources Management 24 (5):941-958

Costanza R, dArge R, deGroot R, Farber S, Grasso M, Hannon B, Limburg K, Naeem S, Oneill RV, Paruelo J, Raskin RG, Sutton P, vandenBelt M (1997) The value of the world's ecosystem services and natural capital. Nature 387(6630):253-260

Ercin AE, Aldaya MM, Hoekstra AY (2011) Corporate Water Footprint Accounting and Impact Assessment: The Case of the Water Footprint of a Sugar-Containing Carbonated Beverage. Water Resour Manag 25 (2):721-741

Fahey B, Jackson R (1997) Hydrological impacts of converting native forests and grasslands to pine plantations, South Island, New Zealand. Agric For Meteorol 84(1-2):69-82

FAO (2001) The World's Forests 2000: resolution of $1 \mathrm{~km}$, based on 1992-93 and 1995-96 AVHRR data. Food and Agricultural Organization, Rome, Italy

FAO (2006) Global Forest Resources Assessment: progress towards sustainable forest management 2005. Food and Agriculture Organization, Rome, Italy

FAO (2009a) ForestSTAT. Food and Agriculture Organization, Rome, Italy

FAO (2009b) Global map of yearly actual evapotranspiration: resolution 5 arc minutes, for the period 1961-1990. Food and Agriculture Organization, Rome, Italy

FAO/CEPI (2007) Recovered paper data 2006. Food and Agriculture Organization, Rome, Italy

Farley KA, Jobbagy EG, Jackson RB (2005) Effects of afforestation on water yield: a global synthesis with implications for policy. Glob Chang Biol 11(10):1565-1576

Ge L, Xie G, Zhang C, Li S, Qi Y, Cao S, He T (2011) An Evaluation of China's Water Footprint. Water Resour Manag 25(10):2633-2647

Gerbens-Leenes W, Hoekstra AY, van der Meer TH (2009) The water footprint of bioenergy. Proc Nat Aca Sci USA 106(25):10219-10223

Gonzalez-Garcia S, Berg S, Feijoo G, Moreira MT (2009) Environmental impacts of forest production and supply of pulpwood: Spanish and Swedish case studies. Int J Life Cycle Assessment 14(4):340-353

Hoekstra AY (2009) Human appropriation of natural capital: A comparison of ecological footprint and water footprint analysis. Ecol Econ 68(7):1963-1974 
Hoekstra AY, Chapagain AK (2007) Water footprints of nations: Water use by people as a function of their consumption pattern. Water Resour Manag 21(1):35-48

Hoekstra AY, Chapagain AK (2008) Globalization of water, sharing the planet's freshwater resources. USA, Blackwell Publishing, Malden

Hoekstra AY, Chapagain AK, Aldaya MM, Mekonnen MM (2009) Water footprint Manual: state of the art 2009. Water Footprint Network, Enschede, the Netherlands

ITC (2006). Statistics International Trade Centre, SITA - Statistics for International Trade Analysis. International Trade Centre. www.intracen.org/mas/sita.htm.

Jackson RB, Jobbagy EG, Avissar R, Roy SB, Barrett DJ, Cook CW, Farley KA, le Maitre DC, McCarl BA, Murray BC (2005) Trading water for carbon with biological sequestration. Science 310 (5756):1944-1947

Montesinos P, Camacho E, Campos B, Rodríguez-Díaz JA (2011) Analysis of Virtual Irrigation Water. Application to Water Resources Management in a Mediterranean River Basin. Water Resour Manag 25 (6): $1635-1651$

NCASI (2009) Water profile of the United States forest products industry (NCASI) National Council for Air and Stream Improvement. National Council for Air and Stream Improvement, Inc., National Triangle Park, NC

UNECE/FAO (2010) Forest product conversion factors for the UNECE region. United Nations Economic Commission for Europe. Food and Agriculture Organization of the United Nations, Geneva, Switserland

Van Oel PR, Mekonnen MM, Hoekstra AY (2009) The external water footprint of the Netherlands: Geographically-explicit quantification and impact assessment. Ecol Econ 69(1):82-92

Velázquez E, Madrid C, Beltrán MJ (2011) Rethinking the Concepts of Virtual Water and Water Footprint in Relation to the Production-Consumption Binomial and the Water-Energy Nexus. Water Resour Manag 25(2):743-761

Wichelns D (2010a) Virtual water and water footprints offer limited insight regarding important policy questions. Int J Water Resour Dev 26(4):639-651

Wichelns D (2010b) Virtual water: A helpful perspective, but not a sufficient policy criterion. Water Resour Manag 24(10):2203-2219

Wilk J, Hughes DA (2002) Simulating the impacts of land-use and climate change on water resource availability for a large south Indian catchment. Hydrolog Sci Journal-Journal Des Sci Hydrologiques 47 (1):19-30 